\title{
Research on Credit Evaluation of Cross-border E-commerce Negotiation
}

\author{
Zhang Yuantian \\ Associate Researcher of Government Economic Research Center, Chinese Academy of Governance \\ Chairman of Hoarded Fortune Group (Singapore), Beijing, 100089, China
}

Keywords: Cross-border e-commerce, Credit, Evaluation

\begin{abstract}
With the further development of the Belt and Road Initiative, cross-border e-commerce trade in China has also witnessed rapid development. With the continuous growth of the volume of merchandise transactions and the continuous expansion of overseas markets, cross-border e-commerce has gradually become a new business model of foreign trade. Because of the disadvantages of e-commerce, the credit issue has become the bottleneck of the sustained and healthy development of cross-border e-commerce. Based on the cross-border credit status of cross-border e-commerce in China, the paper analyzes briefly the credit problems existing in cross-border e-commerce transactions and puts forward several suggestions on how to improve the credit rating of cross-border e-commerce.
\end{abstract}

With the deepening development of the "Belt and Road" Initiative, cross-border e-commerce in China is developing rapidly. The main export trade is B2B and B2C, accounting for about $90 \%$ of China's total foreign trade. As the main body of cross-border e-commerce, foreign trade enterprises are faced with many uncertainties due to the network virtuality and openness of e-commerce carriers under the environment of increasingly serious information asymmetry, which brings credit issues to the participants from different countries and regions. This also leads to a series of credit problems, and severely restricts the improvement of cross-border e-commerce credit evaluation system. As an important part of the cross-border e-commerce credit system, the negotiation credit rating system is of great significance to the study the credit system based on enterprises with cross-border e-commerce as the main and promote the fast and sound development of cross-border e-commerce.

\section{Advantages of Credit Evaluation of Cross-border E-commerce Negotiation}

As to cross-border e-commerce, whether it is the National Development and Reform Commission, the Ministry of Commerce or the General Administration of Customs, the People's Bank and other relevant departments are actively involved in cross-border e-commerce related issues including formulated, promulgated or implemented a series of laws and regulations. Although there are no exclusive laws and regulations on the credit issues of cross-border e-commerce transactions or negotiation in the country yet, there are many laws and regulations covering such issues as: On June 1st, 2012, the State Administration for Industry and Commerce issued the Regulations on the Regulation of Online Commodity Trade and Services involving multiple subjects such as consumers, operators, service providers and trading platforms. On August 29, 2013, nine ministries including the Ministry of Commerce and the National Development and Reform Commission released "Opinions on Implementing Policies Related to the Retail Export of Cross-border E-commerce", put forward six measures on the problems encountered in the development of cross-border e-commerce and proposed the establishment of an e-commerce export credit system with the purpose of improving the current credit system and Market Order; In 2013, the Ministry of Commerce issued "Implementation Opinions on Promoting E-commerce Applications", which mentioned accelerating the construction of such supporting systems involving cross-border e-commerce logistics, payment, supervision and credit. And with the continuous promotion of the legislative procedure, it also plays a protective role in the standard development of 
cross-border e-commerce negotiation credit. It also provides a good environment for the establishment of a cross-border e-commerce negotiation credit system.

Judging from the development of China's import and export trade in recent years, the total volume of China's import and export trade has been increasing year by year. In 2013, the total volume of import and export trade has risen to No. 1 in the world with a total volume of 41,600 U.S. dollars. As an important part of China's foreign trade cross-border e-commerce, the proportion of cross-border e-commerce is also increasing year by year with the expansion of its influence. On the other hand, the demand of China's foreign enterprises and individual consumers for the export of cross-border e-commerce in China is also huge. According to the report, over 34 million U.S. consumers buy Chinese goods through cross-border online shopping in 2013. The total transaction reached 49.7 billion yuan, becoming the world's number one. Under favorable domestic and international economic conditions, cross-border e-commerce in China must hold the right to speak in the negotiation of e-commerce in order to ensure its superiority, especially in the credit regulations; otherwise it will lose its advantages.

The development of cross-border e-commerce is inseparable from the support of information technology. To hold the leader position, cross-border e-commerce in China need to further solve the credit problems in the transaction process, and obviously, establishing a perfect credit rating system needs a good information technology environment. In China, the continuous development and progress of big data technology, platform technology and authentication technology have provided technical support for the development of cross-border e-commerce and the establishment and improvement of credit rating system.

\section{Problems in Credit Evaluation of Cross-border E-commerce Negotiation}

Social credit system is an important evaluation system under the socialist market economic system in our country. It consists of a series of laws, regulations and institutions to assist or protect the social system in which the credit transaction can proceed smoothly in the market economy. China is now in an era of market economy. As the degree of marketization continues to increase, the degree of perfection of the social credit system is also set higher. At present, with the active advocacy of the government of the country, some provinces and municipalities have made some achievements in the construction of social credit system. However, from a national perspective, problems of the social credit system still exist. For example, a large number of enterprises in the Chinese economic market do not have enough understanding of credit, and the general lack of internal rules and regulations related to the credit system and many other issues. The imperfect social credit system brings many drawbacks to various economic activities. The most obvious is that it severely restricts the development of China's credit rating system, which in turn causes an endless stream of credit problems that cannot be obtained effective solution with the rapid development of cross-border electronic commerce in our country.

\section{Improve Cross-border E-commerce Negotiation Credit Rating System}

As to e-commerce activities, a good credit environment can effectively reduce the phenomenon of information failure, and can promote the development of market economy. Because of the relatively late start of e-commerce in our country, the current e-commerce credit environment is still at a relatively backward stage and is not enough to support the long-term development of cross-border e-commerce in China. Affected by the credit environment of domestic e-commerce, cross-border e-commerce enterprises in our country generally have credit problems in their trading activities. Some enterprises haven't realized the impact of negotiation credit evaluation on their own enterprises and haven't put themselves into the e-commerce credit evaluation system in construction. Only from the domestic e-commerce infrastructure to support the environment to strengthen the domestic e-commerce credit environment, creating a mature social credit environment, to enhance the cross-border e-commerce business credit awareness so that we can solve the root causes of the low awareness of cross-border e-commerce negotiation credit rating, and thus promote the 
construction of cross-border e-commerce credit rating system.

Cross-border e-commerce transactions often involve many countries and regions. Each country and each region has a different credit rating criterion, making it difficult to achieve reunification in the actual transaction process and cause a variety of disputes. Therefore, China should first improve its own cross-border e-commerce credit standards, strengthen the legislative work, and improve and refine various laws and regulations on cross-border e-commerce. We can learn from developed and international standards from Europe and the United States, integrate with the international standards, and combine our actual development with the international standards to comprehensively enhance the standards of the credit evaluation system for cross-border e-commerce negotiations in China.

Cross-border e-commerce negotiation credit evaluation system is related to all aspects of cross-border e-commerce business data and information, but these data and information belong to different enterprises or different government departments. Because competition exists among enterprises and the separation of different departments, data and information cannot be shared, often resulting in the phenomenon of isolated islands of information. Therefore, government departments should establish a credit service platform, and encourage enterprises to share data and information on the platform, or open government data resources to relevant departments and enterprises so as to reduce cross-border barriers of building e-commerce negotiation credit platform.

\section{Improve Cross-border E-commerce Related Supporting System}

The development of cross-border e-commerce trade cannot be separated from the cooperation and support of related industries such as logistics service, insurance service and payment service. Although the development of e-commerce in our country is at the leading position, the supporting system of cross-border e-commerce is not refined. The cooperation and coordination between each link is not enough, and the problems emerge in an endless stream, which aggravates the credit risks of the cross-border e-commerce activities. Consequently, the construction of the negotiation evaluation system becomes more difficult. Therefore, by making those facilities and services related to cross-border e-commerce activities, such as logistics services and payment services, perfect and sound, we can provide guarantee for the construction of cross-border e-commerce negotiation credit system.

\section{References}

[1] Chen Zhixiong. Construction of Cross-border E-commerce Credit Evaluation System in the Background of Big Data [J]. Times Finance. 2017 (20).

[2] Cong Zhenjiang. Research on the Improvement of Credit Evaluation Methods of E-commerce Platform [J]. E-commerce. 2013 (01).

[3] Hu Weixiong, Wang Chong. Analysis of E-Commerce Credit in China Based on Game Theory [J]. Electronic Technology. 2012 (11).

[4] Ni Cheng, Sun Ke, Zhai Shuai. Research on Credit Risk of Cross-border E-commerce [J]. Dissemination and Copyright. 2016 (01).

[5] Luo Dan, Li Hua, Tang Laifeng, Kang Yaxin. Research on Mianyang City’s Credit Supervision System for Cross-border E-commerce Under Crowd sourcing [J]. Dissemination and Copyright. 2017 (09). 